\title{
立体角比と心理的負荷の相対性による黄金分割に関する考察 GOLDEN SECTION BY THE RELATIVITY BETWEEN SOLID ANGLE RATIO AND PSYCHOLOGICAL STRESS
}

\author{
荻谷哲朗* \\ Tetsuro KARIYA
}

\begin{abstract}
The information system constructed as an visual cognition model through solid angle ratios shows the results below.
1. If the schemata is constructed by the perceptual circulation through the process of education and experience, solid angle ratios 1 : golden proportion ${ }^{i}\left(=1: 0.61803399^{i}\right)$ can be corresponded to psychological stresses $1: 2^{i}$.

2. By the design works, psychological stress can be set to any plus proportion, so that relativity between solid angle ratio and psychological stress can be controlled to explain orders such as Greek on the same system above.
\end{abstract}

Keywords : proportion, solid angle ratio, golden section

entropy, value, efficiency

プロポーション, 立体角比, 黄金分割, 平均情報量, 評価, 効率

1. はじめに

プロポーションに関連しては,ル・コルビュジェによるモデュ

ロールの理論文1), ジェイ・ハンビッジによるダイナミック・シンメ

トリー文2), エルンスト・モーゼルによるクライス・ジェオメトリ

义2）などが著名であるが，日本に於ても，丹下文，池邊文）をはじ

め, 多くのモデュール研究が行われた。柳は西洋のみならず建築を 含む美術作品について規準線と黄金比による分析をしている坟)吝)。 最近の建築立面に関する黄金分割の研究としては, ミース・ファン. デル・ローエの作品を取り扱った一連の佐野の研究があり文(6) 文7), また,ル・コルビュジェの作品を取り扱った一連のプラダンと浅野 による研究があげられる(8) 文9)。いずれも立面が黄金比に分割され る建築があることを明示しているが, 黄金分割を人間の知覚システ ムや情報システムの問題としてはとらえてえていない。

ここに於て，本論文の目的は，人間の視覚情報システムを立体角 比と人の直接的な印象評価によらない心理的負荷(評価值维)を通じ てモデル化し, 情報システムの中での問題として扱い, モデル上で の立体角比と評価値会确との相対性から導き出される黄金分割につい
ての検証にあり，メディアとしての建築の，面情報の黄金分割によ る制御に関するコードの提案である。
2. 基本的用語の定義
(1) プロポーション, シンメトリーとハーモニー
ウィトルウィウスの建築書では, 建築的構成に於て、「……゙リ シア語でアナロギアといわれる比例から得られる。比例とは，あら ゆる建物において肢体および全体が一定部分の度に従うことで,こ れからシュムメトリアの理法が生まれる」ものとして, シュムメト リアが示されている文(0)。これは,「建物各部の寸法の比が簡単な数 字であらわされることである」文11)。部分の形態の決定に於てそれ を取り巻く部分との相対的関係が重要であり, また, 一方で, 部分 の意味や評価により決定・微調整されるべき事が述べられている。 そうした均衡状態の追及の結果としてシュムメトリアの達成に拏が る事が，具体的な例を示しつう述べられている。
「プロポーションは, 審美的に見て特定の対象の不等の部分と全 体との関係が一致ないしは調和している事をいう。シンメトリーが 


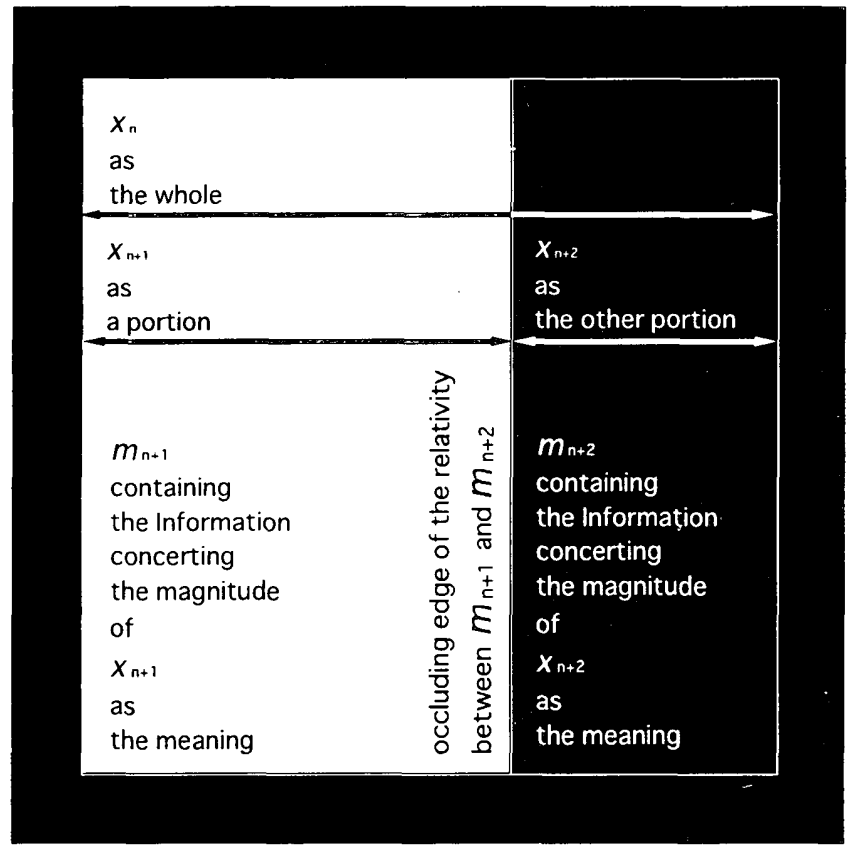

図 1 プロポーションとハーモニーの関係

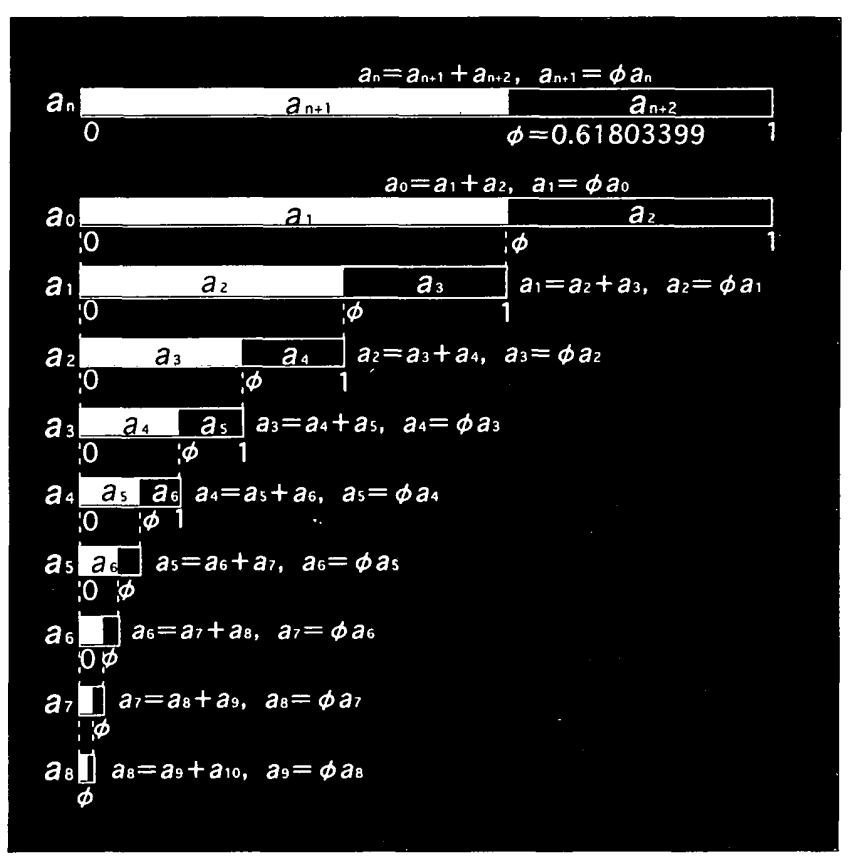

図 2 黄金比数列の定義と二項対立関係の図式
同一平等の部分と部分の関係を意味し, 全体との関係より部分相互 の関係を強調するのに対し, プロポーションはその逆の関係を重視 する。また量的な関係を重んずる点で，質的な関係を重んずるハー モニーと区別される」。ハーモニーはそれぞれ性質を異にする二つ 以上の各部分が，一つの全体的統一を形成して，しかもそこに美的 な均衡が見いだされる場合をいう」义12)。

即ち図 1 に示される様に, 全体 the whole $X_{n}$ を, 1 本の遮蔽 縁 occluding edge で, 部分 portion $x_{n+1}$ と $x_{n+2}$ に2 分割する事 ができるとすれば, プロポーションとハーモニーを成立させる遮蔽 縁は, 形態的に全体を分割する結果として，それぞれの部分の持つ 重要性 magnitude としての意味 $m_{n+1}$ と $m_{n+2}$ の相対的関係を調 和させる様に規定する事になる。

プロポーションとハーモニーは図3のように，同じ幅をもつ $2 つ$

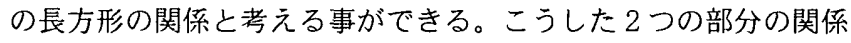
は，特にその部分の幅が $0 に$ 近似されるときには，図4のように2 線分の長さの関係となる。これにより，2つの長方形の面積の関係 としてプロポーションと八ーモニーを考えられる。これを更に発展 させると任意の 2 つの部分の面積関係，または立体角(比)の関係に なる。建築的要素の全てを線分や長方形に帰することは不可能であ り，また建築には様々な装飾がありえ，矩形以外の形態も存在する ことを考えると, 任意の 2 つの部分の面積又は立体角の相対的関保 においてプロポーションを考察する事には意義があろう。

(2) 衝撃性眼球運動と滑動性眼球運動

人間の網膜の一部は視神経の密度が高く特別に解像力が良くなつ ており，視線の半径 2.6 度以内を中心窩， 0.7 度以内を中心小窩と 言う。視覚的に対象を探索するとき，興味ある地点に向けて視線を つぎつぎに無意識にジャンプさせている。このような運動を衝撃性 眼球運動 saccade と言う。また，中心窩のみが視覚に有用なので はなく, 視覚情報の統合には, 視力の劣る網膜周辺部からの周辺視 も役割を果たしているようである。対象物がゆっくり動いていると きは, 対象を中心窩に捉えて，その動きに合わせて眼を無意識に滑 らかに回転させて追跡している。滑らかな眼球の運動を滑動性追跡 眼球運動 smooth pursuit eye movement という义13)。中心視は, 中心窝における, 中心精密視の機能をもつた衝撃性と滑動性追跡眼 球運動の連続により短期記憶に蓄えられるものである。短期記億に 残りやすい視覚的情報の構造としては,こうした眼球運動上の 2 項 間の関係であり, プロポーションが理解されるのは, 主としてこの

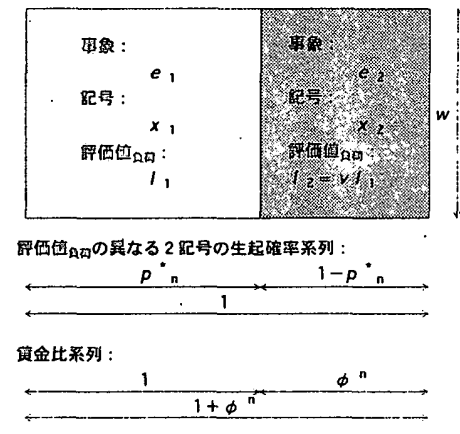

図 3 評価值媎 異なる 2 長方形の場合

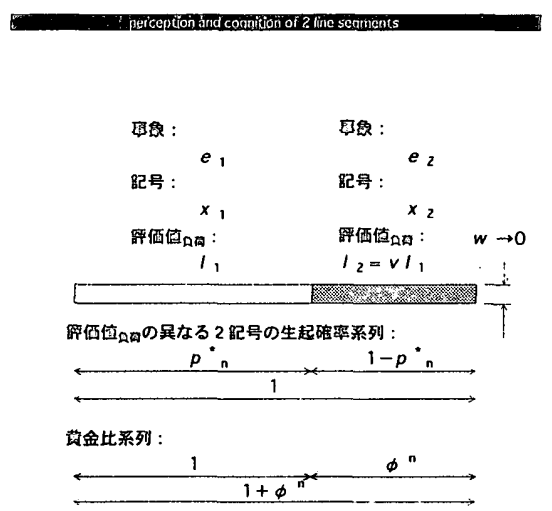

図 4 評価値员茼の異なる 2 線分の場合

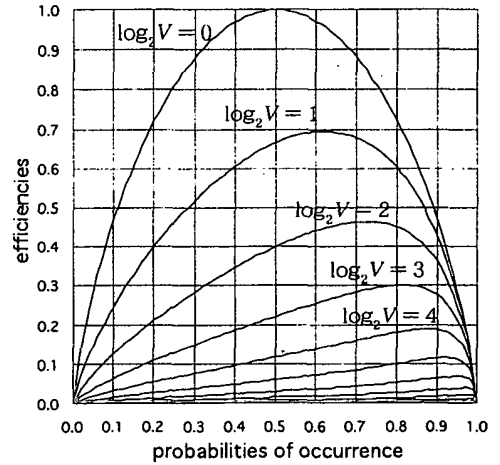

図 5 立体角比, 評価値会荷 と効率分布 


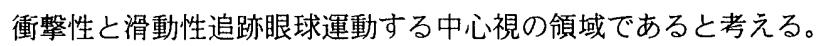

\section{(3) 黄金比数列}

黄金比はギリシア時代の外中比分割 division in extreme and

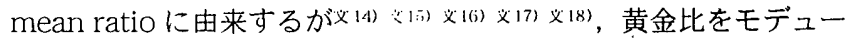
ル体系として用いるには数列にすることが望ましく, 黄金比数列と して以下のように定義できる。

・等比数列 geometric progression : $a_{\mathrm{n}}=\phi a_{\mathrm{n}-1} ; 1>\phi>0, a_{0}>0, \mathrm{n}=1,2,3, \ldots$

・フィボナッチ数列 Fibonacci sequence :

$$
a_{n-1}=a_{n}+a_{n+1}
$$

従って，両者を満たすとき，

$$
\begin{gathered}
\forall \mathrm{n}, \mathrm{a}_{\mathrm{n}-1}=a_{\mathrm{n}}+\phi \mathrm{a}_{\mathrm{n}}=(1+\phi) \mathrm{a}_{\mathrm{n}}=(1+\phi) \phi \mathrm{a}_{\mathrm{n}-1} \\
\quad \therefore 1=\phi+\phi^{2} \\
\quad \phi=(\sqrt{5}-1) / 2=0.61803399 \cdots
\end{gathered}
$$

また, 黄金比数列の定義と二項対立関係を図示すると図 2 になる。

\section{(4) 知覚の許容誤差}

アレキサンダーによれば, 人間の知覚の特性の 1 つに弁別間とい うものがあり,長方形に関しては 2 辺の此が $6 \%$ 変化してもそれを 区別することはできない义(19)义18)。従って黄金比 $0.61803399 \cdots$ …対 して, $0.58095195 \cdots(94 \%) \sim 0.61803399 \cdots(100 \%), 0.61803399$ $\cdots(100 \%) \sim 0.65511602 \cdots(106 \%)$ の間等は区別はできず，知覚の 許容誤差となる。現実の建築の設計条件では, ディテールの意匠の 効果で補正する他, 建築全体側からのトップダウン処理的な黄金比 等の適用と, 建築のディテール側からのボトムアップ処理的な調整 と葛藤の中で, 最終的なプロポーションの均衡状態が上記程度の範 囲において決定される。従って，本論文においても，上記の知覚の 許容誤差に対する考慮がなされるものとする。

\section{(5) 立体角比}

ギブソンは立体角を有する人間のまわりの包囲光について論じて きているが, 写真は包囲光の一標本を記録したものであり，頭部で 見ているものに類似すると言う义20)。即ち立体角写影の魚眼レンズ で撮影した写真でなくとも, 写真で撮られたような包絡線で囲むこ とができる画像は近似的に立体角を有するとみなすことができる。

本論文では，全球（4 $\left.\pi \mathrm{sr} ， 720^{\circ}\right)$ 上の任意の立体角の設定領 域 $X=\bigcup_{k=1}^{m} X_{k}(100 \%)$ に占める部分領域 $X_{k}$ の割合として立体角比 （\%）を定義し分析する义211文22)。

(6) 評価值貝荷 図式

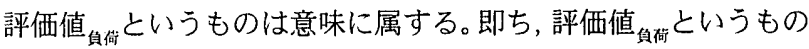

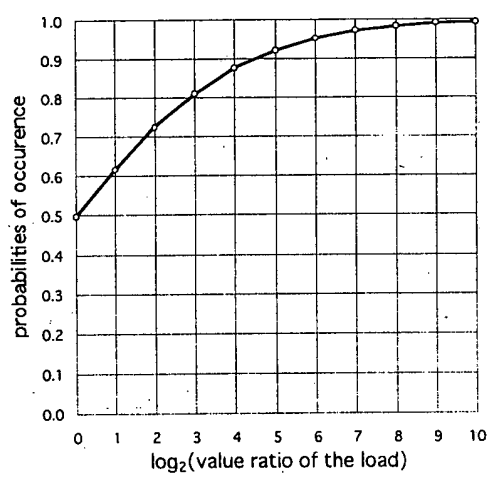

図 6 立体角比, 評価値自荷之最大効率
は，知覚循環义23)により生じる，世界を認知したり外界に働きかけ たりする土台となる人間の内的な枠組である予期図式 schemaの上 に組立てられた心理的負荷であり，経験の産物である。評価値自何と して，貨幣価値のようなものを設定した場合には，ほとんどの人に 共有される図式を形成しやすいが, 建築を含む情景の印象などの場 合には, 全ての人々が同じ経験をする事が不可能なため, 個体差を 考えるまでもなく，共通な図式の形成には限度があると予想でき る。従って建築に関する基礎的素養がある水準に至っている被験者 の場合においてはじめて, 比較的共通の認知や評価に至る事を期待 できる。評価値負何の基盤となる図式の形成は, 十分な経験或は教育 と，わかり易い情報の構造に依存していると考えられる。プロポー ションが比較的わかりにくいのはプロポーションという言葉自体の 意味が理解できないためにわからないケースが多いと考えられる。 ここでは一定の建築的教育や経験を積みプロポーションに関する図 式が形成された人々を対象として,そのプロポーションの認知モデ ルを考察するものであり, 瞬間的にプロポーションの善し悪しが理 解出来る水準に至っている人々の場合をモデルとして想定する。

(7) テクスチュアとレイヤー

境界が設定できない程意味が曖昧なもの同士は, そもそも 2 項対 立の図式にのるとは言えず,そうした関係に於ては本論文における プロポーションは定義されない。この曖昧な状態を, 2 項に限らず, 一般的な立体角を有する面にまで拡張して考えたときには, 個別の 面として識別されず, 個別の遮蔽縁が識別されない部分についての 問題であり,このような部分の状態を本論文ではテクスチュアと呼 ぶ。テクスチュアは, 形態的に曖昧で, 内部構造のアイデンティティ や構造がはっきりしないだけではなく，同時に，各部分の部分とし ての意味も暧昧な状態である。このような部分内部に関しては部分 と全体との関係は生じない。建築の立面的構成を観察する視点は限 り無いが, その全ての可能な視点において, 内部のアイデンティ ティが生ぜずテクスチュアとみなされる部分は, 部分と全体との関 係において重要度が低い。そして, より多くの視点から見てテクス チュアとなりにくい部分は, よりアイデンティティが高く, 重要度 の階層構造においてより高い階層, すなわちより重要なレイヤー (層)に属すと考えることとする。

（8）平均情報量（エントロピー）

立体角比は想定された視野全体に占める着目された部分の割合で ある。従って, 中心視の範囲で視野を想定する時, 瞬間的な眼球運 動により想定された視野全体がスキャンされると仮定できるなら ば, その時注目された部分が人間の短期記億に記銘され, その部分 の全体に対する比率が, 全体に於て選択される確率, 即ち生起確率 に相当すると考える。また，一般的なアイデンティティの定義であ る「対象物を他のものから見分けている事，独立した実態として認 めている事」は要するに「知覚（認知）の対象物たるにふさわしい 特性」であり，情報路として認知システムを設定している場合には， 「対象物の認知という事象の生起特性」である。このアイデンティ ティの特性を最も単純に表現するものとして，1次元的に表現する ならば, 情報理論における認知という事象の生起確率である立体角 比である坟1)义22)。従って，シャノンの情報理論により，平均情報 量（エントロピー）を求めることができる。ここに於て，平均情報 量は，与えられた対象の全ての部分々々が均質であればある程大き 
くなることから，与えられた対象の均質性の指標となる。

\section{3. 立体角此と心理的負荷の相対性のモデルによる検証 \\ （1) 1 因子情報路モデル注1) 文24)}

シャノンの情報理論では価值や意味を対象としていない。シャノ ンの情報理論が扱っているのは, 形態的な情報（情報の物理的特性） である。これに対し価值や意味の一種である評価值筫背をあわせて扱 う1因子情報路モデルにおいて, 記号の数 $m$ を 2 項に限定した場 合を検討してみると，注2)，図 5，図6の様になる。特に図 5 を見 るとわかる通り，2 項についての評価値貟研が等しいとき, 即ち，1， $=I_{2} \quad\left(v_{0}=1\right)$ の時には, 効率は平均情報量の事である。そし て, この時更に 2 項についての生起確率が等しければ, 効率=平均 情報量 は最大となる。記号同士の評価值負有が異なるほど, 最大効 率が低下し, また, 最大効率即ち均衡状態を与える生起確率が大き くなる。注2)により2 項の場合, 評価值自郡 $I_{1}: 1_{2}=1: 2 （ v_{1}$ $\left.=2^{1}\right)$ のときには, 効率が最大となる均衡状態における生起確率 が, 黄金比 ゆになる事がわかる。本論文では, プロポーションの視 賞的情報処理のモデルとして，この2項のみの関係に着目した 1 因 子情報路モデルをあてる事にする。ここで黄金比系列 (比例定数 $\phi^{\prime \prime}$, $\mathrm{n}=1,2,3, \ldots)$ にある任意の 2 項 $: a_{n 1}, b_{11}$ について, 大きいほうの 項 : $a_{n}$ と, 2 項の大きさの和 $: a_{n}+b_{n}$ の比を求め, 注 2)で求めた,

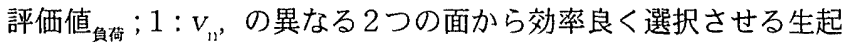
確率系列; $p^{*}{ }_{11}$ と, 表 1 に於て比較すると, $\mathrm{n}=0$, および, 1 , に ついては，注 2)により，両系列の完全一致が確認される。それ以 上のnについては，表1により誤差1\%末満で一致する事が本論文 において確認された。このように記号数 2 つの情報路における平均 評価值負何をできるだけ小さくし平均情報量をできるだけ大きくす る様な均衡状態における生起確率分布は, 2 項間の評価值貝荷 $V_{1}$ が $1: 2$ である場合に丁度 $1: 1+\phi=\phi=0.6180399 \cdots$ になる ばかりでなく, 一般に, 2 項間の評価值期湔 には，誤差 $1 \%$ 末満で， $1: 1+\phi^{i}=1 /(1+0.6180399 \cdots i)$ と なることが本諭において確認された。

この 2 項（線, および, 面）のみの関係に着目し情報路として設 定された人間の視覚的認知システムモデル上では, 評価値負尚尚は心 理的負荷のことと言えるから, 各記号ごとの心理的負荷が与えられ ているときに，「平均評価值翼售をできるだけ小さくし平均情報量を できるだけ大きくする様な均衡状態に於ける生起確率分布」とは, 「 2 項による平均心理的負荷をできるだけ小さくしつつ，2 項の立
体角比をできるだけ均等にする均衡状態」である。従って, 教育や 経験により図式の形成ができるならば，「2 項間の心理的負荷が均 等であると認知できるとき， 2 項による平均心理的負荷をできるだ け小さくし, 2 項間の立体角比をできるだけ均等にする均衡状態に すると， 2 項間の立体角比は均等に 2 分割される」，また， 「 2 項間 の心理的負荷の 2 倍差が認知できるとき， 2 項による平均心理的負 荷をできるだけ小さくし，2 項間の立体角比をできるだけ均等にす る均衡状態にすると, 2 項間の立体角比は黄金比に分割される」の みならず,「2 項間の心理的負荷が 2 倍単位の等比級数的に認知さ れるならば，2 項による平均心理的負荷をできるだけ小さくし，2 項間の立体角比をできるだけ均等にする均衡状態では，2 項間の立 体角比が誤差 $1 \%$ 末満で 黄金比系列にのる」事を示している。

(2) 逆 1 因子情報路モデル生1)义24)

逆 1 因子情報路モデルを利用する事で, 記号の数 $m$ が 2 項に限 られた場合では, 情報源 $X=\left\{x_{1}, x_{2}\right\}$ の生起確率分布 $\left\{p_{1}, p_{2}\right\}$ が与 えられているとき，そのような条件の下で，できるだけ平均評価値 自们を小さくすると同時に，平均情報量をできるだけ大きくするよう な均衡値を与える情報路における評価値毁㣂分布 $\left\{1_{1}, 1_{2}\right\}$ を求める事 ができる。

即ち，1因子情報路モデルの場合とは逆に，「2 項間の立体角比 が均等に 2 分割されるとき， 2 項による平均心理的負荷をできるだ け小さくする均衡状態にすると， 2 項間の心理的負荷が均等である と認知できる」, また,「2 項間の立体角比は黄金比に分割されると き, 2 項による平均心理的負荷をできるだけ小さくする均衡状態に すると, 2 項間の心理的負荷の 2 倍差が認知できる」のみならず, 「2 項間の立体角比が誤差 $1 \%$ 末満で 黄金比系列にのるとき，2 項 による平均心理的負荷をできるだけ小さくする均衡状態では, 心理 的負荷が 2 倍単位の等比級数的に認知される」事がモデル上で確認 された。即ち，本論文における人間の視角的認知システムでは，黄 金比系列の分割の状態 (立体角比 $1: \phi^{\prime}(=1: 0.61803399 \cdots i)$ ) が与えらるならば，そのようなプロポーション（均衡值）を与える 心理的負荷として，1:2iが与えられ得る事が確認された。

従って, 知覚循環的に 1 因子情報路モデルと逆 1 因子情報路モデ ルの結果をあわせて考察すると, 黄金分割に従った建築を繰り返し 経験したときには，2iで代表されるような，はっきりとした心理的 負荷の差として記銘され易くなることが期待できる。この事は, 黄 金分割が,わかりやすさや図式の形成しやすさと強い関連をもつ事 を示すものであり,また知覚循環の結果として黄金分割に至る事を

表 1 評価值

\begin{tabular}{|c|c|c|c|c|c|c|c|}
\hline \multicolumn{2}{|c|}{ 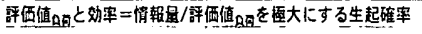 } & \multicolumn{4}{|c|}{ 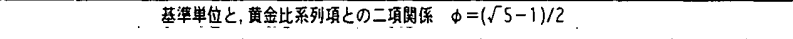 } & \multicolumn{2}{|c|}{ 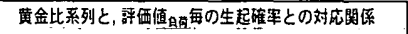 } \\
\hline$v_{n}$ & $p \cdot n$ & $a_{\pi}$ & $b_{n}$ & $a_{n}+b_{n}$ & $a_{n} /\left(a_{n}+b_{n}\right)$ & $\left(a_{n} / a_{n}+b_{n}\right) / p_{n}$ & error \\
\hline 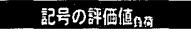 & 挋号の生起磪算 & 基徍覀位 & 黄金比系列頊 & 二項の和 & 基㔼戦位項/二項の和 & 比列 & 蛅差 \\
\hline$v_{0}=2^{0}=1$ & $p^{*}{ }_{0}=0.49999999$ & 1 & $\phi^{0}=1.00000000$ & $1+\phi^{0}=2.00000000$ & $1 /\left(1+\phi^{0}\right)=0.50000000$ & 1.00000002 & $0.00 \%$ \\
\hline$v_{1}=2^{1}=2$ & $\rho^{*}{ }_{1}=0.61803399$ & 1 & $\phi^{\prime}=0.61803399$ & $1+\phi^{\prime}=1.61803399$ & $1 /\left(1+\phi^{\prime}\right)=0.61803399$ & 1.00000000 & $0.00 \%$ \\
\hline$v_{2}=2^{2}=4$ & $p^{*}{ }_{2}=0.72449195$ & 1 & $\phi^{2}=0.38196601$ & $1+\phi^{2}=1.38196601$ & $1 /\left(1+\phi^{2}\right)=0.72360680$ & 0.99877824 & $0.12 \%$ \\
\hline$v_{3}=2^{3}=8$ & $p^{*}{ }_{3}=0.81165232$ & 1 & $\phi^{3}=0.23606798$ & $1+\phi^{3}=1.23606798$ & $1 /\left(1+\phi^{3}\right)=0.80901699$ & 0.99675313 & $0.32 \%$ \\
\hline$v_{4}=2^{4}=16$ & $p^{*}{ }_{4}=0.87716687$ & 1 & $\phi^{4}=0.14589803$ & $1+\phi^{4}=1.14589803$ & $1 /\left(1+\phi^{4}\right)=0.87267800$ & 0.99488253 & $0.51 \%$ \\
\hline$v_{s}=2^{s}=32$ & $p^{*}{ }_{3}=0.92300175$. & 1 & $\phi^{5}=0.09016994$ & $1+\phi^{5}=1.09016994$. & $1 /\left(1+\phi^{5}\right)=0.91728818$ & 0.99380979 & $0.62 \%$ \\
\hline$v_{\underline{6}}=2^{6}=64$ & $p^{*}{ }_{6}=0.95326419$. & 1 & $\phi^{6}=0.05572809$ & $1+\phi^{6}=1.05572809$ & $1 /\left(1+\phi^{6}\right)=0.94721360$ & 0.99365277 & $0.63 \%$ \\
\hline$v_{7}=2^{7}=128$ & $\underline{p}^{*} ?=0.97235549$. & 1 & $\phi^{7}=0.03444185$ & $1+\phi^{\prime}=1.03444185$. & $1 /\left(1+\phi^{7}\right)=0.96670489$ & 0.99418876 & $0.58 \%$ \\
\hline$v_{8}=2^{s}=256$ & $p^{*}{ }_{8}=0.98398126$. & 1 & $\Phi^{8}=0.02128624$ & $1+\phi^{8}=1.02128624$ & $1 /\left(1+\phi^{8}\right)=0.97915742$ & 0.99509763 & $0.49 \%$ \\
\hline$v_{9}=2^{9}=512$ & $p^{*}{ }_{9}=0.99086975$. & 1 & $\phi^{9}=0.01315562$ & $1+\phi^{9}=1.01315562$ & $1 /\left(1+\phi^{9}\right)=0.98701521$ & 0.99610994 & $0.39 \%$ \\
\hline$v_{10}=2^{10}=1024$ & $\underline{p}^{*}{ }_{10}=0.99486509$. & 1 & $\phi^{10}=0.00813062$ & $1+\phi^{10}=1.00813062$ & $1 /\left(1+\phi^{10}\right)=0.99193496$ & 0.99705474 & $0.29 \%$ \\
\hline
\end{tabular}


意味している。即ち, 仮に一度黄金分割が好ましいと評価されると， 図式が形成されやすいために, 知覚循環の結果として, 再び黄金分 割に従った対象を経験したときには, 好ましいという評価を誘発し やすい事を支持している。フェヒナーはどんな比率をもつ長方形が 最も美しく感じられるかを実験的方法により研究し, 近似的に見る と350名の男女の被験者の $75.6 \%$ 黄金比に近い長方形を美しいと したという文14汶18が，このことはまた上記の結果を支持している。

また,この関係は心理量の判断に関するパワー法則 (Stevensの 法則, 1957, 1961) ×25),

$$
J=k I^{\prime \prime}
$$

( $J:$ 心理量の判断, $I:$ 物理的強度, $p:$ べき乗, $k:$ 任意の定数 $)$ を満たしていることが注 3)に示される。

\section{4. 建築の黄金分割の事例分析}

以下においては今までの議論が, 一体, 現実の建築的環境のなか でどの様に現象するかについて検討する。

3 次元としての建築空間には, 古典的には基本的に矩形をべース とする建築が多かったために, 主として各々の立面を正面から見た 場合の姿がその立面的印象を決定づけていたとみなすことができ， 黄金分割も基本的な構成としてはその面上で考察することが適して いた。しかるに，矩形の立面であっても様々な凹凸があるのが普通 であり,アイレベルからの見上げの効果を考慮する必要がある場合 が多く，一方現代では必ずしも矩形をべースとしない建築が増えて いることもあり，3次元に適した黄金分割に類するプロポーション や美的効果を考慮することに意義があるようになった。そこで, 将 来を見据えて必ずしも矩形をべースとしなくともよい方法論とし て，立体角比を採用したわけである。しかしながら，本論文におい ては，まだ導入段階であるということで，わかりやすさのために矩 形や線形に限定して分析を進めている。

\section{(1) 比例関係と心理的負荷の関係}

図7には，左側の黄金比長方形に対して，右側に黄金比系列で幅 のみ調整した長方形が接した， 2 長方形の組合せが描かれている。 更に, 右側の黄金比系列の長方形は, 逆 1 因子情報路モデルに基づ く均衡状態における心理的負荷の表現方法として,ここでは技術的 限界からモノクロームの濃度変化で表現する。心理的負荷として は，他には，たとえば，重量感，剛性，硬度，閉鎖感，色彩感，リ ズム感, 安心感, 安全性, 安定性, 公共性, ...等, 様々な意味の 尺度が想定できる。そこでここで心理的負荷として, 具体的に何を 想定するかは，色々に考えられるが，ここでは類似の事例はないの で, 左側の黄金比長方形を白としたために, 黒さの強度について検
討するのが適当と考えた。もし，左側の黄金比長方形が黒の場合に は，右側を相対的に黒から白へと変化さぜることで, 明度の強度に ついての検討にすることもできると考えられる。

(1) 一番左の組合せでは左右の長方形の形態が同じで, かつ濃度が 同じであるので， 2 長方形の関倸は明らかに対等・並置である。

（2）これに対し一つ右の組合せでは，立体角比が低減した分につい て濃度が増加されている。果たしてこの関係が調和のとれたもので あるかは, 人により判断が完全には一致しないだろう。しかしなが ら, 濃度が全く同じ状態を想定してみると, 濃度の加減により, 少 なくとも調和感が異なる事は多くの人が認め得るであろう。

(3) もし, 左から一つ右の組合せが, 濃度が全く同じ状態のものよ りは, 調和感が高いとす扎ば, 一連の組合せにより示されている様 に, 立体角比が低減した分について濃度を増加する事により, 調和 感が高まる事になる。定量的な濃度の加減については, 全ての人が 納得する保証はないが，こうした定性的な傾向については，多くの 人が納得するものであろう。そして，こうした操作により調和が成 立するならば，プロポーションは，立体角比で代表されるような， 形態的特性のみにより決定されるのではなく, 少なくとも, 濃度の 評価が重要な役割を担い得るのであり，おそらくは，心理的負荷が, 何らかの形で重要な役割を果たしている事になる。

(2) ギリシア建築のオーダー

現実の建築の構成要素は複雑であり, 全て矩形で考えられるよう なものではない。しかしながら，図8～図 13 に示されたギリシア 建築のオーダーのような場合には, 近似的に, 矩形で構成されてい ると考える事ができよう。また, ウィトルウィウスの建築書で示さ れたシュムメトリアは，一見, 本論文における人間の視角的認知シ ステムのように黄金比系列の分割の状態を示していないように見え る。しかしながら，上記のシステムは，対立する関倸にある 2 項間 の心理的負荷の比例の 2 の指数系列と, 2 項間の立体角比の比例の 黄金比系列が対応するというのであり，実は，デザイン・ワークと は心理的負荷を任意の正の比例に意図的に設定することである。こ のように, 立体角比と心理的負荷の相対性に着目すると, ギリシア 建築のオーダーのようなものも, 同じシステムの尺度上で語ること ができるのである。

図 8d〜13dのドーリア式 Dolic Order, 図 8i〜13i のイオニア 式 Ionic Order に従った古典的建築の立面の部分で検討してみると, 特に, 列柱廊 colonnade で構成される中間部については, 前項(1) で検討されたような, 心理的負荷の立体角比に与える效果, 即ち, プロポーションに与える効果が見られる。

（1）図 8d／図 8i 屋根や梁などの上部構造を支持するものとして

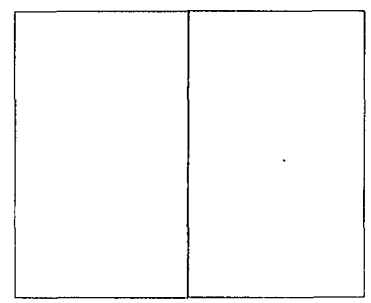

心理的負荷 $1: 2^{0}=1$

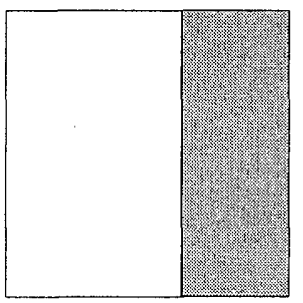

$1: 2^{1}$

$1: \phi^{1}$

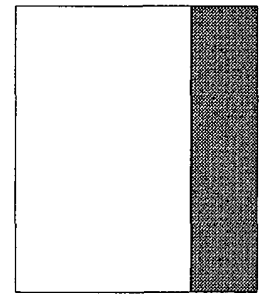

$1: 22$

$1: \phi^{2}$

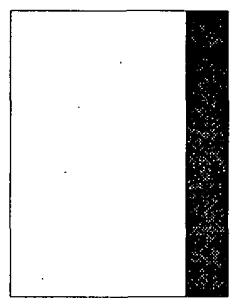

$1: 2: 3$

$1: \phi^{3}$

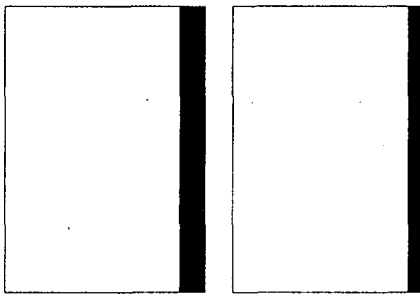

$1: 21$

$1: 2:$

$1: \phi^{\prime}$

$1: \phi^{5}$ 
の柱は, 上部の加重を担っているが, ドーリア式の柱の柱身に比べ て,イオニア式の柱の細身の柱身の意匠は勒性が高く、シャープな 心理的負荷を与えるとすれば, 列柱廊の部分の柱と開口部の立体角 比は, イオニア式の方がドーリア式よりも柱の割合が少ないときに 心理的負荷との均衡状態に近づく事になる。

（2）図 9d/図 9i 独立柱で想定するとき，柱身が細身になると軸 方向加重による曲がり, 即ち, 柱身の座屈強さの心理的負荷が弱く なると考元られるが，これは，支持力の心理的負荷が弱くなると言 う事もできる。従って，エンタブレチュアと列柱廊の組合せとして の柱身の安定性に関しての心理的負荷としては弱くなる事になる。 従って, 立体角比との均衡状態を成立させるためには, 柱身が細身 のイオニア式の方が, ドーリア式に比べて, エンタブレチュアに対 する列柱廊の部分の心理的負荷が弱い㑯向にある事になり, 即ち, エンタブレチュアの立体角比が減少傾向になる事になる。

（3）图 10d/図 10i エンタブレチュアの立体角比が隇少傾向にあ る事, 即ち, 細身でありながら, エンタブレチュア内部の立体角比 との均衡状態を成立させるためには, エンタブレチュアの内部の アーキトレーブが, 積載加重と自重による曲げ応力に抗するのに十 分な鞄性の心理的負荷を与える意匠でなければならない事になる。 (4) 図11d/図11i柱身が細身であるときには，基壇が受ける軸 方向加重に対する抵抗力の心理的負荷が少なくてよいと考える事が できる。従って，上家と基壇の組合せとしての安定性に関しての基 壇の心理的負荷としては減少傾向になる事になる。従って立体角比 との均衡状態を成立させるためには，柱身が細身のイオニア式の方 が,ドーリア式に比べて，上家に対する基壇の部分の心理的負荷が 減少傾向，即ち，基壇の立体角比が減少傾向でよい事になる。

（5）図 12d/図12i基壇の立体角比が減少傾向にある事, 即ち, 薄 身でありながら，基壇内部のプロポーションを成立させるために は, 基壇が積載加重による曲げ応力に抗するのに十分な勒性の心理 的負荷を与える意匠でなければならない事になる。

（6）图 13d/図 13i柱身が細身で，勒性の心理的負荷が大きい意 匠のときには, 上部構造との接点である柱頭や，基壇との接点であ る柱礎の意匠は弾力性の大きい心理的負荷が与元られるような意匠 を要求される事になる。従って，逆に，柱身が太身のドーリア式の 方がイオニア式に比べ, 柱頭が弾力性の心理的負荷の少ない意匠で よい事になり，また柱礎が省略された意匠でよい事になる。

この様にして，立体角比と，その組合せである構造を通じて伝達 される意味や心理的負荷の調和と相対性により，ギリシア建築の オーダーが構成されている様子を説明する事ができるであろう。

また, 様々な構成要素が伝達する意味や心理的負荷の組合せによ り,プロポーションが成立しハーモニーを感じさせる均衡状態が相 对的，あるいは，相互浸透的に微妙に变化するために，仮にブライ ンド・スケールとしての黄金比との均衡状態に強い関連があるとし ても，単純図形の様には完全な黄金分割は表には見えてこないで, 一見色々な比例関係があるかの様にダイナミックに現象する事が想 定される。しかしながら，もとより，全ての事例について説明する 事は不可能であるし，定量的に特定はできないが, 定性的には知覚 循睘を前提とする 2 項に関する 1 因子情報路モデルと逆 1 因子情報 路モデルの考え方で説明ができる例がある事が明かになった。

(3) 黄金比と黄金分割の関係の建築設計方法論的適用
ところで現実の建築設計のなかでは, 一体，全体のなかのどこの 部分に対し，モデュールのような物を当てはめるのが有効であり， どういう部分に当てはめても無効であるかという選別が必要であ る。即ち, 部分と全体の関係を分析する必要が生じて来るわけであ る。言い替えると, 識別できないような部分, 即ち, アイデンティ ティのない部分に関しては,そのようなものは適用しても無駄であ る。つまり，建築を観察する視点は限りなくあるが，その全ての可 能な視点に於て，テクスチュアとみなされる部分については，モ デュールの適用は無意味である。そして，より多くの視点から見て テクスチュアとなりにくい部分は, 上りアイデンティティが高いわ けであり,プロポーションのコントロールがより有意義であり, 重 要度の階層構造に拉いてより高い階層, 即ち,レイヤーに属してい る事になる。

アイデンティティそのものが知覚循環に基づき図式との照合によ り生起するものであり, また, プロポーションに関して, 部分と部 分の関倸や, 部分と全体との関係に配慮した途端に, 知覚循環によ る図式の上に構築される意味や心理的負荷を参照する事になる。

しかしながら, 現実の条件の中で, 重要なレイヤーから順にトッ プダウン処理的に黄金分割を適用していくと, 詳細部分のレイヤー に至るまでもなく，才法の収まりに破綻をきたす事になる。また， より重要なレイヤーのプロポーション関係より,下位のレイヤーの プロポーション関係のアイデンティティが高いとすれば、識別され る意味や心理的負荷, または, 重要度が意図したものと異なる事に なるのでそうした取り扱いは本来原則的ではない。しかしながら， 5. 建築と黄金分割(1)(2)、における检討により，プロポーションを 成立させる調和感は, 上位や同じレイヤーに含まれる部分や全体と の関保だけではなく，建築設計上の操作で本来下位のレイヤーに含 まれていた部分が強調されアイデンティティを持ち始めるとその影 響を受け，その故に，下位のレイヤーに含まれる部分の意匠により プロポーションの補正やコントロールが可能である事がわかる。

この事は, 現実の設計に於ては，上位のレイヤーから順にプロ ポーションを設定し, トップダウン的にとりあえず処理し, 下位の レイヤーの状況に応じて, 下位のレイヤーから意匠的な補正やコン トロールを施して行くことになり,例光ば下位のレイヤーにおける 既製品や詳細設計の寸法の収まりに問題が生じるときにはボトム アップ的にプロポーションの逆補正をしていけば良い事になる。

設計途中におけるプログラム変更に於ても, 直接関係するレイ ヤーを中心に, 必要に応じ, ボトムアップ, あるいは, トップダウ ン的に，補正を波及させていけば良いことになる。

\section{6. まとめ}

以上の検討により以下の様な 2 つの結論を得, 今後の研究に $2 つ$ の方向性を与える。

\section{(1) 本論文における人間の視角的認知システム}

教育や経験による知覚循環的図式の形成により, 黄金比系列の分 割の状態（立体角比 $\left.1: \phi^{i}\left(=1: 0.61803399^{i}\right)\right)$ が与えられる ならば, そのようなプロポーション (均衡値)を与える心理的負荷 として，1:2'が対応し得る事がモデルとして示された。

(2) ブラインド・スケールとしての黄金比系列

上記のシステムは，対立する関倸にある 2 項間の心理的負荷の比 


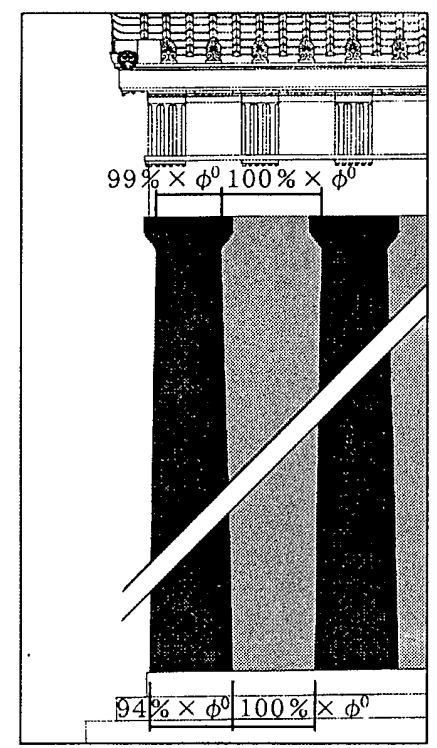

図 $8 d$ /図 $8 i$ 柱と開口部の比例
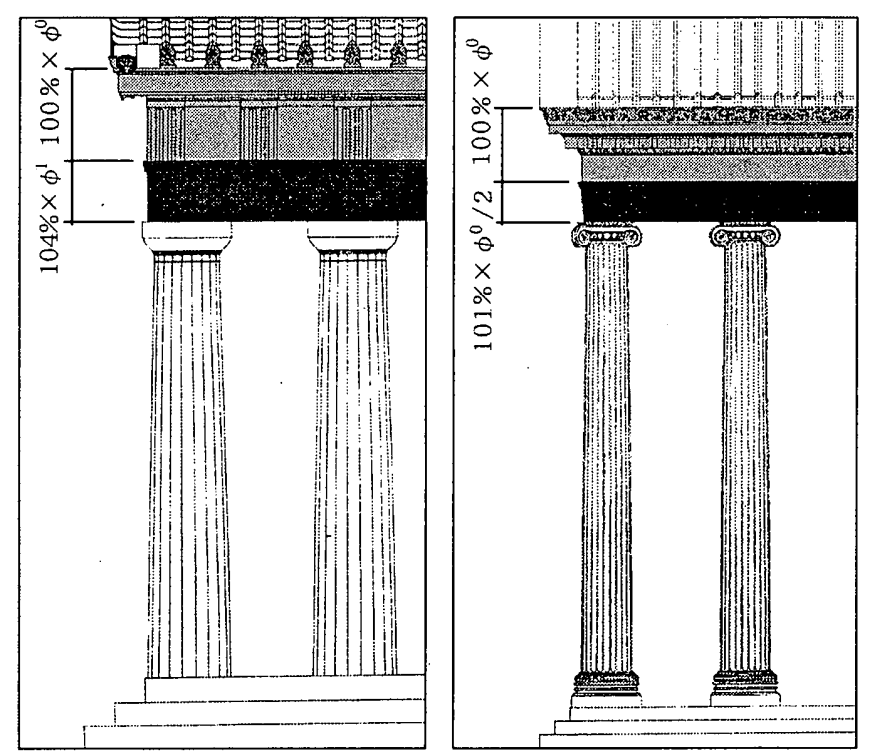

図 10d／図 10i エンタフฺレチュア内のアーキ.トレーブの比例

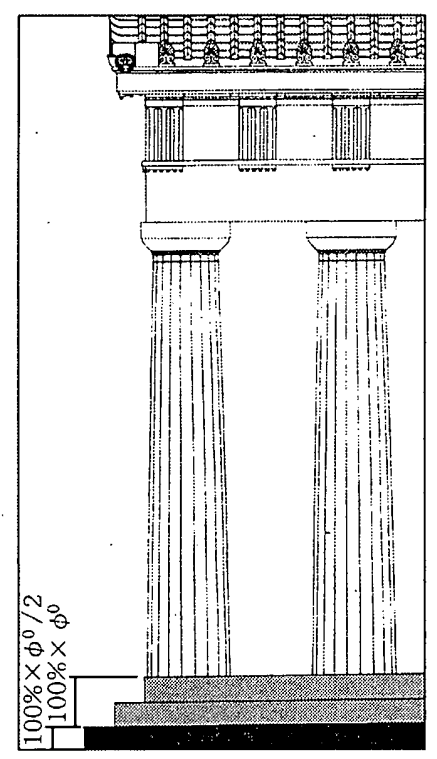

図 $12 d /$ 図 $12 i$ 基壇内の比例

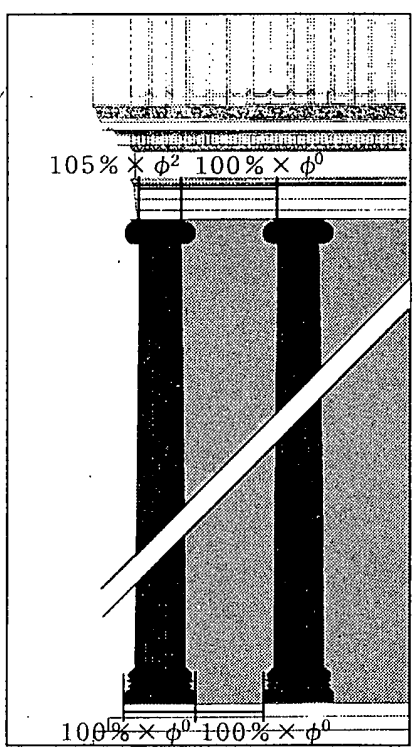

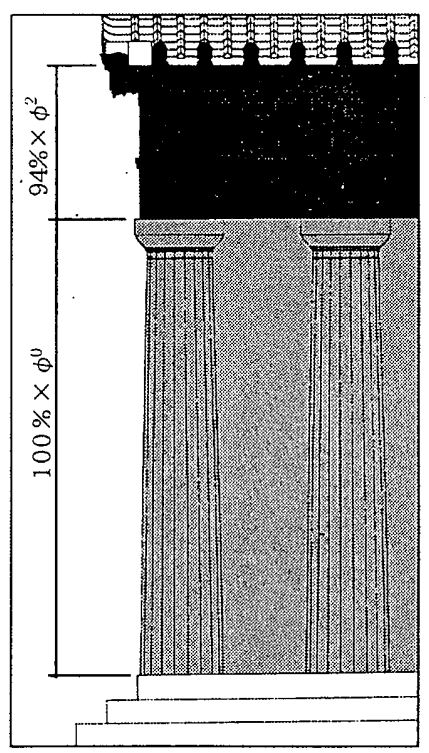

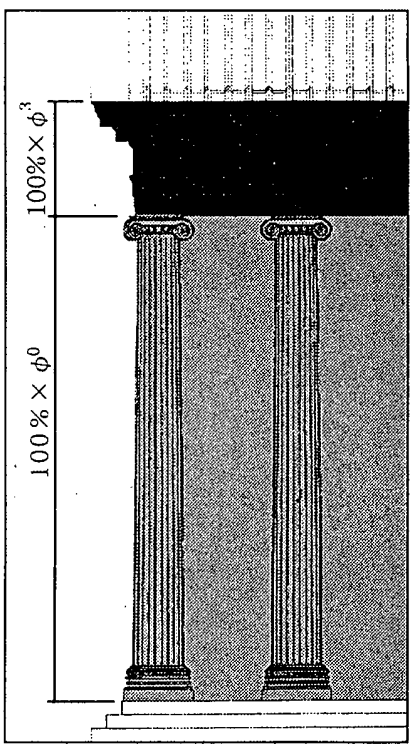

図 9d/図 9i エンタブレチュアと列柱廊の比例

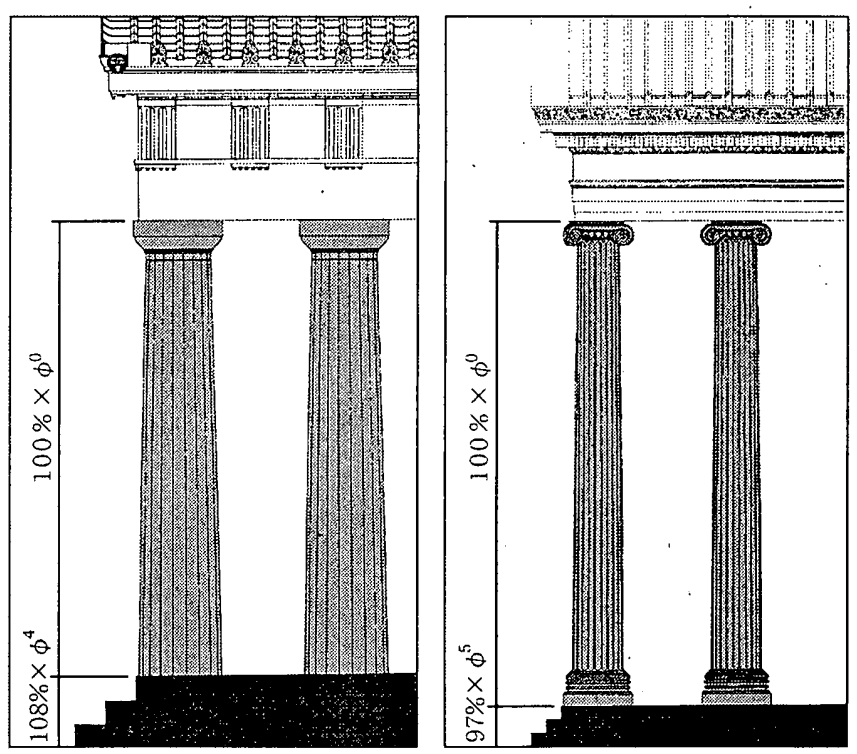

図 $11 d /$ 図 $11 i$ 柱身と基壇の比例
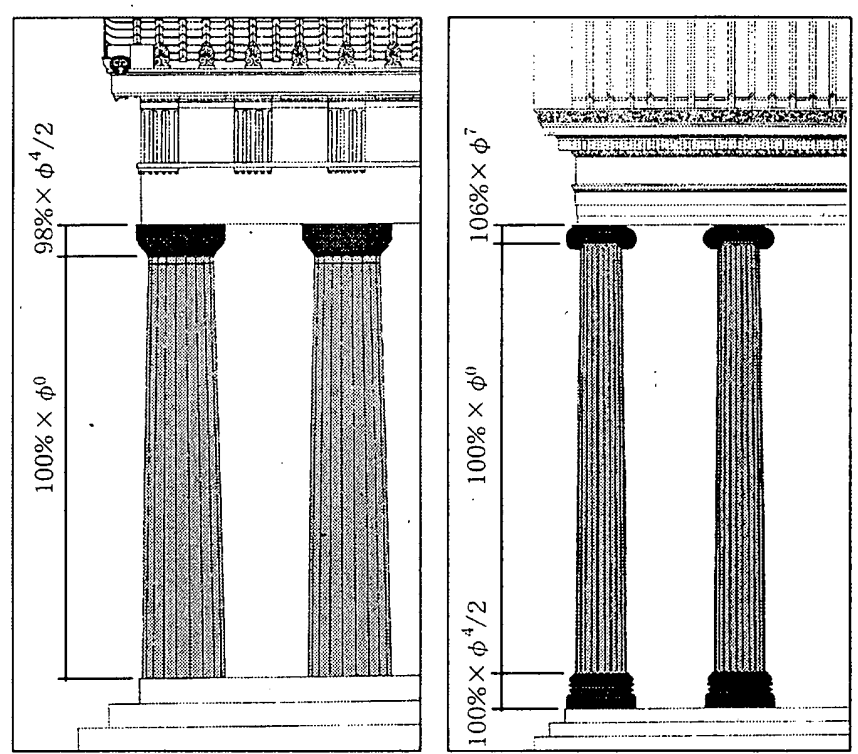

図 13d／図 13i 柱頭之柱礎の意匠

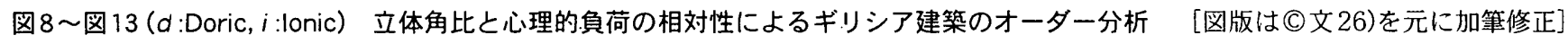


例の 2 の指数系列と, 2 項間の立体角比の比例の黄金比系列が相対 的に対応するというのであり，実は，デザイン・ワークとは，心理 的負荷を任意の正の比例に意図的に設定することでもある。このよ うに，立体角比と心理的負荷の相対性に着目すると，ギリシア建築 のオーダーのようなものも, 同じシステムの尺度上で語ることがで きる事が示された。

\section{注}

注 1）（1） 1 因子情報路モデル文24)

制約条件として，情報源 $X=\left\{x_{1}, x_{2}, \cdots, x_{1 n}\right\}$ の評価値自枌分布 $\left\{l_{1}, l_{2}\right.$,

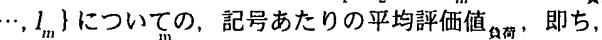
$L=\sum_{i=1}^{m} l_{i} p_{i}$

をできるだけ小さくする（条件 I）と同時に，目的関数として，記号 あたりの平均情報量，即ち、 $H=\sum_{i=1}^{11} p_{i} h_{i}=-\sum_{i}^{111} p_{i} \log p_{i}$

をできるだけ大きくする（条俳且）ために，効率（単位評洒値晧あた りの斗均情報量)，即ち、

$E=H / L$

の最大值を与えるような情報路における生起確率分布 $\left\{q_{1}, q_{2}, \cdots, q_{m}\right\}$ を求める問題。

また、これに関連して以下の定理が成立している。

（定理） 1 因子情報路モデルに於て生起確率 $p_{i}$ が $p_{i}=W_{0}^{-11}, i=1,2, \cdots, m$

によって与えられるための必要かつ十分な条件は（条件 I)，(条件 II） の成市する事である。ここに $W_{0}$ は方程式 $W n+W 12+\cdots+W^{\prime \prime}=1$ の让根である。

2. 逆 1 因子情報路モデル文24)

1 因子情報路とは逆に生起確率を与えて評価値自荷を求めるという問 題。1 因子情報路モデルと同じ定理が成立する。

注 2）評価値 荷の異なる2つの記号を效率良く生起させる生起確率 通信路 (知賞・認知過程) に於て，2つの記号 (面); $x_{1}, x_{2}$ を通信 (注視)するものとする。各々の生起確率（選択比率；立体角比）は, $p_{1}=p, p_{2}=1-p ; 0 \leqq p \leqq 1$, で与えられ，各記号の評価值分荷（因 子）の比率を， $l_{1} 、 l_{2}=v l_{1} ; v \geqq 0$ ，であるとする (cf.1 因子情報路)。 このとき,

・記号あたりの平均情報量 :

$$
H=p_{1} h_{1}+p_{2} h_{2}=-p \log _{2} p-(1-p) \log _{2}(1-p)
$$

・記号あたりの平均詊佂値

$$
L=I_{1} p_{1}+I_{2} p_{1}=I_{1} p+I_{1} v(1-p)
$$

・効率（単位評価值 不あたりの情報量）： $E=H / L$

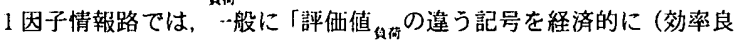

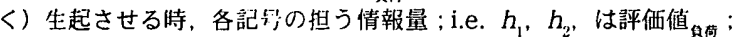
i.e. $I_{1}, I_{2}=v I_{1}$, に比例する」から，効率を最大にして，「選択の自 由度をできるだけ確保しながら,負荷はできるだけ少なくしたい。」と すれば, そのときの生起確率 : $p^{*}$ は,

$\log _{2} p^{*}: \log _{2}\left(1-p^{*}\right)=h_{1}: h_{2}=l_{1}: l_{2}=1: V$ $\log _{2} p^{* v}=\log _{2}\left(1-p^{*}\right)$ $p^{* v}+p^{*}-1=0$

で与えられる。従って， $v=2^{\prime \prime}=1$ のとき

$p^{*}{ }^{1}+p^{*}{ }_{0}-1=0$ $p^{*}{ }_{0}=0.5$

また, $v=2^{1}=2$ のとき,

$p^{*}{ }^{2}+p^{*}{ }_{1}-1=0$

$\left(p^{*}{ }^{2}+1 / 2\right)^{2}=1+(1 / 2)^{2}=5 / 4$

$p^{*}{ }_{1}=(\sqrt{ } 5-1) / 2=0.61803399 \cdots(=\phi:$ 黄金比 $)$

·般のvについては，図5にホす様に、コンヒューターにより生起確

率0.01毎に遂次計算した上で, 図6に亦す様に、極大值近傍について 小数点以ド 10 桁まで計算し，小数点以ド 8 桁まで求めた。

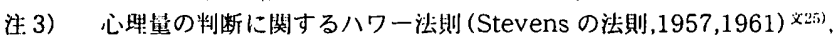
$J=k I^{\prime \prime}$

( $J:$ 心理量の判断, $I:$ 物理的強度, $\mathrm{p}:$ へきき乗, $k$ : 任意の定数) にお Wて, $(J: 2$ 項の心理的負荷同士の比率, $I: 2$ 項の立体角比同士の比

率) とすれば，立体角比が同じとき， $J_{0}=1, I_{0}=1$

であるから

$$
1=J_{0}=k I_{0}{ }^{p}=k 1^{\nu}=k
$$

黄金分割のとき、

であるから

$$
J_{1}=2, I_{1}=\varnothing
$$

$$
2=J_{1}=I_{1}^{p}=\phi^{\nu}
$$$$
1=\log _{2} 2=p \log _{2} \phi
$$

従って。

$$
p=\left(\log _{2} \phi\right)^{-1}
$$

$$
J=I\left(\log _{2} \phi\right)^{-1}
$$

でなけれぱならない。

一般に，黄金比系列にのるときには，

でるから、 $J_{i}=2^{i}, I_{i}=\phi^{i}, \quad i=0,1,2,3, \cdots$

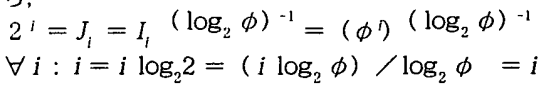

\section{引用・参考文献}

文 1）、ル・コルビュジェ, 吉阪隆正訳, モデュロール I , II，鹿島出版会，1967 丈2）柳亮, 黄金分割一ヒラミッドからル・コルビュジェまで一, 美術出版社 1965

文 3）所下健：，現実と創造丹下健。：1946-1958，美術出版社，p.242，1966

文4）油遥陽、デザインの鍵一人間・建築・方法一，丸善株式会社, p.124, p. 150,1979

文 5）柳亮, 繶黄金分割一日本の比例 法隆寺から浮世絵まで一, 美術出版 社, 1977

文6）佐野潤一,ミース・ファン・デル・ローエの新国立ギャラリーの立面 におけるブロボーションについて, 日本建筑学会計画系諭文集 No.504, pp.261-268, 1998-2

文7）佐野潤…, ミース・ファン・デル・ローエによるレイク・ショア・ド ライブ・アハートメントのファサードのブロボーションにおけるダブ ルスクエアと黄金比，日本建築学会計画系諭文集 No.537,pp.319324, 2000-11

文8）フラダン・ジャヤ, 浅野捷郎、ユニテ・ダビタシオンの建築形態と比 例について一ル・コルビュジェの建築形態と比例の研究, 日本建築学 会計画系論文集 No.535,pp.291-296, 2000-9

文9）ブラダン・ジャヤ，浅野唗郎，メソン・スイスの建筑形態と比例につ いてール・コルビュジェの建築形態と比例の研究, 日本建築学会計画 系論文集 No.544，pp.303-308，2001-6

文 10）森田度-一訳, ウィトルウィウス建築書, 東海大学出版会, pp.1-15, pp.69180, 1979

文 11）井:充夫, 建築美論の歩み, 鹿島出版会, pp.33-40, 1991

文12）下中弘編，哲学事典、平凡社、1971

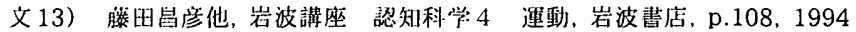

文 14) Huntley, H.E., The Divine Proportion-A Study in Mathemati cal Beauty -, Dover Publications, Inc., pp.23-34,pp.62-65, 1970

文15）上垣渉，キリリシア数学のあけほの，日本評論社, pp.162-173, 1995

文 16）ユークリッド原論, 中村幸四郎, 寺坂英孝, 伊東俊太郎, 池田美恵訳, 共立出版株式会社, p.117, 1971

文 17） スチュアート・ホリングデール，数学を筑いた天才たち（上）, 岡部恒治訳, 講談社, pp63-86, 1993 (原典 1989)

文 18）高橋鹰志, 黄金比とその周辺, 日本建築学会編, 第 2 版 建築学便覧 I 計画, 丸善, pp.216-661，1980

文 19) Alexander, C., Perception and Modular Co-ordination, RIBA journal, pp.425-429, 1959-10

文 20) Gibson, J.J., The Ecological Approach to Visual Perception, Lawrence Erlbaum Associates, Inc., pp.237-291, 1986

文 21）荻谷哲朗, 長澤泰, 高橋鹰志, 建築的情景により伝達される情緒的意味に 関する研究，日本建築学会計画系諭文報告集 No.535, pp.147-154, 2000-9

文 22）荻谷哲朗，建築的情景を構成する立体角比の特性に関する考察，日本建築 学会部画系論文報告集, 2001-8

文23）ウルリック・ナイサー,認知の構図一人間は現実をどのようにとらえ るか一，古崎敬、村瀬旻俱，サイエンス社， Pp.20-24、1978（原典 1976)

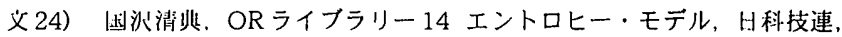
pp.37-64, 1975

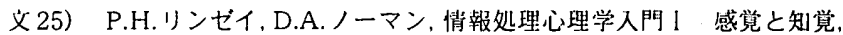
中型幸夫, 箱田裕问。近藤倫明訳, サイエンス社, pp.264-265, 1983 (䅫典 1977)

文26) Stratton, A., The Orders of Architecture,Originally Published by B.T. Batsford Limited, 1931, Plate III , Plate VII, Copyright Studio Editions, 1986 